\title{
Emotional Intelligence and Its Impact on the Organizational Performance-using SEM
}

\author{
Joiceswarnalatha R, V. Murali Krishna
}

\begin{abstract}
There are drastic advancements in the technology. This is having an impact on the world wide organizations which is stressing them to perform better to with stand the competition. In India, one of the largest contributing sectors for the Indian economy is IT sector. Employees are the biggest assets for the organizations to perform well. We can see the number of IT companies cropping up and number of IT companies winding off. We can also see many employees hopping from one organization to other and also few of them being terminated by the organization itself. This study aims to study the employees' capacity to know about themselves, others and their contributions to the organization. This study main intention is to know impact of emotional intelligence levels of the employees from IT sector on their organizational performance levels. The IT professionals of sample size 463 from Hyderabad, Telangana is chosen. Structural equation modeling is used for building the model. It was observed that there was constructive significant impact of emotional intelligence levels of employees on their organizational performance.
\end{abstract}

Index terms: Emotional intelligence, employee engagement, job satisfaction, organizational performance, organization commitment, quality of work life, relationship management, stress, self management, self awareness, social awareness

\section{INTRODUCTION}

The information technology sector of India has drastically increased its contribution towards the economy growth. The study done by Ishmeet and Navjot (2017) reported that the IT industry has tremendously raised its contribution from least to one of the best contributors. There is an enormous development in the IT sector of India. For this sought of development the sector needs very skilled human resources. India possesses good number of universities and educational institutions. Knowledgeable human resources are one of the main reasons for the development of IT sector.

Even though there seems very thing to be great, but we often hear the word retrenchment from the side of companies and job hopping from the side of employees'. Here, raises the question of organizational performance and how well the

Revised Manuscript Received on July 22, 2019.

Joiceswarnalatha $\mathbf{R}^{\mathbf{1}}$, Research Scholar, Bharathiar school of Management and Entrepreneur Development, Bharathiar University, Coimbatore, Tamilnadu, India-641046

rjswarnalatha@gmail.com

V. Murali Krishna ${ }^{2}$, Department of Management studies, SITAMS, Chittoor, Andhra Pradesh, India

employees' handle the situations by themselves. This research is a try to inspect the organizational performance of IT companies and emotional intelligence levels of the IT professionals.

The thought process of performance started from 1990s. Many authors have given their thoughts on organizational performance. Ashworth and Ghobadian (1993) in their study recommended giving importance to other aspects other than the financial measures of the company which have effect on organizational performance. Campbell (1990) in his study argued to differentiate the outcomes as a result of internal factors which are out of the control of employees. Armstrong (2000) with his investigation concluded that the organizational performance is the both the individual behavior and the results.

\section{REVIEW OF LITERATURE}

The dimensions used for measuring the organizational performance are "ability to predict stress, job satisfaction, employee engagement, quality of work life and organization commitment". The dimensions are chosen based upon the past studies done by various authors.

A. Literature on Employee engagement and Organizational Performance:

- Ntwari, A., \& Kule, W. J. (2016) have investigated on role of strategic employee engagement on organizational performance. They selected hotel industry for the study reason. The most important goal of the study is to discover association amid of employee engagement and organizational performance. They have used regression analysis for finding the association. The $\mathrm{R}$ square value is low but showed significant constructive relation among worker engagement and authoritative execution..

- Saima Sultana (2015) has done a study on Effect of Worker engagement for enhancing that authoritative execution. The major intention of research is to get importance of employee engagement in work place and its association with organizational performance. The investigation discovered that tough association exits amid of employee engagement performance.

and 


\section{B. Literature on Emotional intelligence and employee engagement:}

- Sarangi, S., \& Vats, A. (2015) have conducted a research on role of emotional intelligence in employee engagement. The key purpose is to explore emotional intelligence as an input for the employee engagement. There sample unit is professionals working in the Indian organizations. The outcome confirmed that emotional intelligence was considerably and certainly related to employee engagement.

- Mwangi, D. C. I. (2014) has investigated effect of emotional intelligence on employee engagement. The most important intend is should dissect sway about Enthusiastic brainpower on representative engagement around administration colleges. The outcome of study was that emotional intelligence influenced employee engagement.

C. Literature on organization commitment and organizational performance:

- Gul, Z. (2015) has investigated organizational performance effected by organizational commitment. The sample units were from the employees of "public and private sector banks" working at "Lahore, Rawalpindi and Islamabad". The research targeted at identifying force of organization commitment on organizational performance. The results showed moderate correlation between institute obligation and organizational performance and impact of society obligation was strong on organizational performance.

- Berberoglu, A., \& Secim, H. (2015) have done a research on organization obligation and professed organizational concert among the health care workers. The study objective was to find the relationship between organization commitment and professed organizational concert. The study fulfilled that there is significant positive bond amid of organization obligation and professed organizational concert.

D. Literature on Emotional intelligence and organization commitment:

- Shafiq, M., \& Rana, R. A. (2016) have done a study on association of emotional intelligence to organization obligation of college teachers. The main plan of investigation is explore association of emotional intelligence and organization commitment. The study outcomes confirmed noteworthy Acquaintanceship of Enthusiastic brainpower for affective, continuation What's more regularizing dedication levels.

- Patiraj and Bhanu (2015) have investigated part played by Enthusiastic brainpower in authoritative duty of the saving money division workers. The study was done in Dehradun. The principal goal of re4search is to find the relationship between emotional intelligence and organization commitment. The results investigation showed that emotional intelligence levels of managers were positively associated with the organization commitment.

\section{E. Literature on job satisfaction and organizational performance:}

- Bakotić, D. (2016) has done a study to find the association of job satisfaction and organizational performance. The major purpose is to find the association of job contentment and organizational concert. The study showed presence of rapport among job satisfaction and organizational concert.

- Shmailan, A. (2016) has done investigation on association of job fulfillment, job concert and worker engagement. The outcome confirmed that there is a link amid of job satisfaction and performance. Further this study also suggested the ways to improve the job fulfillment levels of workers'.

F. Literature on Emotional intelligence and Job satisfaction:

- Papathanasiou, S., \& Siati, M. (2014) has done research on Emotional Intelligence and Job fulfillment in Greek Banking Sector. This paper mainly concentrates on extracting association of emotional intelligence and job fulfillment. The consequences showed that the emotional intelligence levels of workers' are having influence on daily performance and transforms their job satisfaction levels.

- Paiman, et al (2014) has studied association amid of emotional intelligence and job fulfillment: the case of Malaysian Information Technology Professionals. The major objective of this study is to find the association amid of Emotional intelligence and job fulfillment levels of the IT professionals. The outcomes showed that there is noteworthy positive association amid of emotional intelligence and job fulfillment levels of IT professionals.

\section{G. Literature on Stress and Organizational performance:}

- Prasad, K., Vaidya, R., \& Kumar, V. A. (2016) have done an experiment to explore reasons for occupational stress and influence on performance of employees' of supermarkets Hyderabad. The main reason of the paper is find stress levels and its influence on employees' performance. The outcome showed that there is moderate force of stress on the employees' performance.

- Sathya Priya, V. B. (2016) has done an investigation on job stress and effect on employees' performance. The main objective is to find the levels of job stress and its impact on employees' performance. The outcomes showed a negative noteworthy association of stress with employees' performance.

H. Literature on Emotional intelligence and stress: 
- Sharma, R., \& Kumar, P. (2016) has done research on private doctors to explore emotional intelligence and overcoming of stress levels. The main aim was to know influence of Emotional intelligence on stress coping strategies. The investigation revealed emotional intelligence levels of the doctors were moderately effective in managing their stress levels.

Sharma, r. \& Sharma, k. (2014) mulled over those Acquaintanceship about Enthusiastic brainpower and word related anxiety in BPO division. Those principle point for leading this will be should Figure those affinity from claiming Enthusiastic brainpower What's more anxiety. That investigation demonstrated four extents about Enthusiastic brainpower were Hosting critical association for those word related stress levels of the employees'.

I. Literature on quality of work life and organizational performance:

- Quadros, A. R. A. (2015) has done investigation on the employees' opinion on organizational performance. Structural equation model is the chief aspire of research. The model is built on the association of employees' perception with performance measures. The results showed significant relationship with productivity and in turn productivity has relationship with profitability.

- Jaiswal, A. (2014) has done a study on quality of work life. The purpose is to find the quality of work life and its impact over various aspects of organizational performance. From this study the author confirmed that quality of work life was found to be indicator of progress in organization.

\section{J. Literature on Emotional Intelligence and Quality of work life:}

-Manhas, C. (2013) has done the study to bring connection among Passionate Intelligence, caliber from claiming fill in term and employment fulfillment. The comes about demonstrated the secondary correspondence Around passionate intelligence, nature of worth of effort existence What's more vocation fulfillment. Enthusiastic brainpower might have been An capable supporter of nature of worth of effort term Furthermore occupation satisfaction.

- Farahbakhsh, S. (2012) has done an investigation on part played by emotional intelligence in enhancing quality of work life among school principals. The key plan is to find involvement of emotional intelligence in quality of work life. It was observed that there was constructive correlation amid of quality of work life and emotional intelligence. The result also concluded increase in emotional intelligence lead to improved work environment.

\section{K. Literature on Emotional intelligence and} organizational performance:

- Karolis, K. (2016) has done a research on effect of manager's emotional intelligence on organizational performance. The main purpose is to find the association among emotional intelligence levels of the managers and organizational performance. In this study Emotional intelligence was observed to have high association with performance.

- Kalairasi et al (2014) has done a study on emotional intelligence and organizational performance. The major intention of study is to find effect of emotional intelligence on organizational performance. The study results reported constructive involvement of emotional intelligence in organizational concert.

\section{RESEARCH METHODOLOGY}

In this present study, the dependent variable is organizational performance its measuring dimensions are "stress, organization commitment, employee engagement, quality of work life and job satisfaction". The self-determining variable is emotional intelligence its measuring dimensions are "emotional self awareness, emotional self management, emotional social awareness and relationship management". The data is being collected by using structured questionnaire by means of personal interview and through Google docs. The scale used in the questionnaire is likert scale with five dimensions. Depending on the positive and negative type of the question the weights are assigned as 1, 2, 3, 4 and 5. Apart from the dependent and independent variables demographic variables were also used. Demographic variables used were age, gender, education qualification, experience, marital status, shift system, number of family members, distance travelled and number of working hours. The questionnaire is partitioned into three segments. First part is demographic profile of the respondents. Second part is emotional intelligence and third part is organizational performance.

The questionnaire was distributed to 700 IT professionals of Hyderabad where only 524 were returned back out of which 463 were perfect for the study analysis. The samples are selected by using deliberate sampling. The study used both primary data and secondary data. The secondary data is extensively collected from the IT related sites and the primary data is from the IT professionals. 


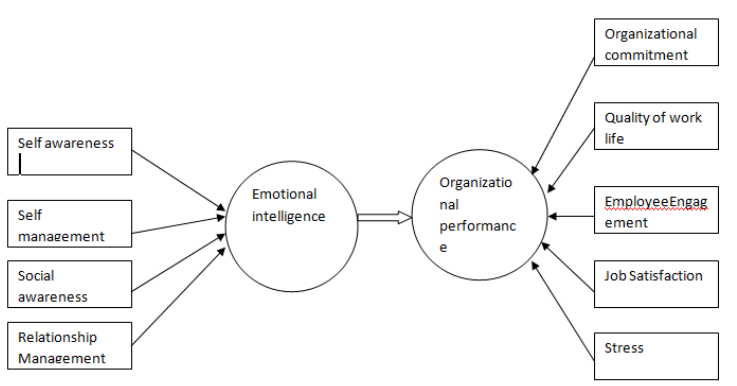

Fig 1 Conceptual model

The above conceptual model is built based up on the gap extracted from the past literatures. The present conceptual study consists of one independent variable and dependent variable. There are nine sub variables in the study.

\section{A. Objectives of the study:}

The study is done based up on the following objectives:

- To study the Emotional intelligence levels of the employees.

- To study the organizational performance with regard to the attributes of employees.

- To investigation the sway of Enthusiastic brainpower levels of the representatives ahead their authoritative execution.

\section{B. Statement of the problem:}

Employees' termination and job hopping has become very common words in the IT sector. At this aspect it is necessary to know the levels of emotional intelligence among the employees'. The present research is an attempt to identify way the employees' deal with their emotions and manage emotions of others. It is also attempted by the researcher to know how the emotional intelligence levels of employees' will have effect on organizational concert. This study may help us to find one of the reasons to know why the IT companies are terminating their employees' and why the employees' often jump from one organization to other.

\section{Research questions:}

RQ1: Is there whatever critical affiliation "around those extents about Enthusiastic brainpower Also measurements for authoritative concert?

$\mathrm{H}_{1 \mathrm{a}}$ : There is significant association between the Ability to predict stress and Emotional Intelligence levels of the employees'.

$\mathrm{H}_{1 \mathrm{~b}}$ : There is significant association between the Emotional intelligence levels of the employees and their job satisfaction levels.

$\mathrm{H}_{1 \mathrm{c}}$ : There is significant association between the Emotional intelligence levels of the employees and their Organizational commitment levels.

$\mathrm{H}_{1 \mathrm{~d}}$ : There is significant association between the Emotional intelligence levels of the employees and employee engagement

$\mathrm{H}_{1 \mathrm{e}}$ : There is significant association between the Emotional intelligence levels of the employees and Quality of work life.
RQ2: Is there any significant association between the Emotional intelligence levels of employees' and their organizational performance levels.

$\mathrm{H}_{2}$ : There is significant association between the Emotional intelligence levels of employees' and their organizational performance levels.

\section{DATA ANALYSIS}

The data is fed into SPSS soft ware and coded. The tools used are descriptive statistics for analysis report of demographic variables; correlation for finding the co-variance between the different elements of Emotional intelligence and organizational performance; regression is used for finding the association and drawing the regression equation and Structural equation modeling is used for building model.

\section{A. Descriptive statistics}

Table. I. Demographic profile of the respondents

\begin{tabular}{|c|c|c|}
\hline $\begin{array}{l}\text { Demographic } \\
\text { variable }\end{array}$ & $\begin{array}{l}\text { No. of } \\
\text { respondents }\end{array}$ & $\begin{array}{l}\text { Percentag } \\
\text { e }\end{array}$ \\
\hline \multicolumn{3}{|l|}{ Gender } \\
\hline Male & 266 & 57.5 \\
\hline Female & 197 & 42.5 \\
\hline \multicolumn{3}{|l|}{ Age } \\
\hline $21-30$ & 364 & 78.6 \\
\hline $31-40$ & 95 & 20.5 \\
\hline $41-50$ & 2 & 0.4 \\
\hline Above 50 & 2 & 0.4 \\
\hline \multicolumn{3}{|l|}{ Education } \\
\hline UG & 213 & 46 \\
\hline PG & 248 & 53.6 \\
\hline Others & 2 & 0.4 \\
\hline \multicolumn{3}{|l|}{ Experience } \\
\hline $0-1$ & 55 & 11.9 \\
\hline $2-5$ & 295 & 63.7 \\
\hline $6-10$ & 83 & 17.9 \\
\hline $11-15$ & 24 & 5.2 \\
\hline Above 15 & 6 & 1.3 \\
\hline \multicolumn{3}{|l|}{ Marital status } \\
\hline Married & 255 & 55.1 \\
\hline Unmarried & 203 & 43.8 \\
\hline Others & 5 & 1.1 \\
\hline \multicolumn{3}{|c|}{ Family members } \\
\hline 2 & 25 & 5.4 \\
\hline 3 & 64 & 13.8 \\
\hline 4 & 119 & 25.7 \\
\hline 5 & 178 & 38.4 \\
\hline 6 and above & 77 & 16.6 \\
\hline \multicolumn{3}{|l|}{ Working hours } \\
\hline $0-6$ & 10 & 2.2 \\
\hline $7-8$ & 6 & 3.5 \\
\hline $9-10$ & 410 & \\
\hline
\end{tabular}




\begin{tabular}{|l|l|l|}
\hline $10-12$ & 27 & 5.8 \\
\hline \multicolumn{2}{|l|}{ Distance travelled } & \multicolumn{2}{|l|}{} \\
\hline $1-5$ & 66 & 14.3 \\
\hline $6-10$ & 99 & 21.4 \\
\hline $11-15$ & 187 & 40.4 \\
\hline $16-20$ & 45 & 9.7 \\
\hline Above 20 & 66 & 14.3 \\
\hline Shift system & 277 & 59.8 \\
\hline Day & 145 & 31.3 \\
\hline Night & 41 & 8.9 \\
\hline Others & \multicolumn{2}{|l}{} \\
\hline
\end{tabular}

The above table 1 shows percentage of respondents. Maximum of the respondents were of the age group of 21-30. Most of the respondents were having PG. The present study samples were having the experience of 2-5 years. The maximum of the respondents worked for 9-10 hours in a day. More number of respondents was working in the day shift.

Table II. Analysis of Demographic variables with the dimensions of Organizational Performance

\begin{tabular}{|c|c|c|c|c|c|c|c|}
\hline \multicolumn{2}{|c|}{$\begin{array}{l}\text { Demographic } \\
\text { variable }\end{array}$} & \multirow{2}{*}{$\begin{array}{l}\mathrm{pc} \\
4.16\end{array}$} & \multirow{2}{*}{$\begin{array}{l}\text { PS } \\
3.99\end{array}$} & \multirow{2}{*}{$\frac{\mathrm{EE}}{4.15}$} & \multirow{2}{*}{$\begin{array}{l}\text { QWL } \\
4.12\end{array}$} & \multirow{2}{*}{\begin{tabular}{|l|} 
JS \\
1.14
\end{tabular}} & \multirow{2}{*}{$\begin{array}{l}\text { OP } \\
1.11\end{array}$} \\
\hline $4 g e$ & Mean & & & & & & \\
\hline $21-30$ & $S D$ & 0.65 & 0.68 & 0.53 & 0.58 & 0.63 & 0.52 \\
\hline \multirow[b]{2}{*}{$31-40$} & Mear & 93 & .96 & 4.18 & 4.08 & 3.98 & 4.02 \\
\hline & $S D$ & 78 & .68 & 51 & 0.54 & 0.64 & 52 \\
\hline \multirow[b]{2}{*}{$41-50$} & Mea & 3.33 & .38 & 3.56 & 3.35 & 3.35 & 3.39 \\
\hline & $S D$ & .47 & .53 & 0.80 & 0.5 & 0.50 & 0.56 \\
\hline \multirow{2}{*}{$\begin{array}{l}50 \text { and } \\
\text { above }\end{array}$} & Mear & 08 & 2.75 & 3.25 & 2.78 & 2.71 & 2.91 \\
\hline & $S D$ & 2.00 & 1.77 & 1.24 & 1.91 & 2.02 & .78 \\
\hline \multicolumn{2}{|l|}{ Fvalue } & 4.39 & 4.39 & 3.09 & 2.83 & 4.66 & 5.13 \\
\hline \multicolumn{2}{|l|}{ Pvalue } & 0.00 & 0.01 & 0.03 & p.04 & $p$ & 0.00 \\
\hline \multirow{3}{*}{\begin{tabular}{|l} 
Gender \\
Male
\end{tabular}} & Mean & 4.06 & 4.00 & 4.16 & 4.12 & 4.07 & 4.08 \\
\hline & $S D$ & 0.73 & 0.67 & 0.51 & 0.57 & 0.63 & 0.53 \\
\hline & Mear & 4.17 & 3.95 & 4.13 & 4.07 & 4.12 & 4.92 \\
\hline Female & $S D$ & 0.63 & 0.67 & 0.57 & 0.6 & 0.67 & 0.54 \\
\hline \multicolumn{2}{|l|}{-value } & 1.67 & -1.67 & 1.56 & 0.52 & 0.95 & 0.01 \\
\hline \multicolumn{2}{|l|}{ Pvalue } & 0.04 & 0.04 & 0.74 & 0.92 & p.81 & 0.69 \\
\hline \multirow{2}{*}{$\begin{array}{l}\text { Educati } \\
\text { pn } U G\end{array}$} & Mean & 4.25 & 4.01 & 4.12 & 4.09 & 4.15 & 4.12 \\
\hline & $S D$ & 0.57 & 0.67 & 0.54 & 0.6 & 0.644 & 0.52 \\
\hline \multirow{2}{*}{$P G$} & Mean & $\beta .97$ & 3.96 & 4.18 & 4.11 & 4.05 & 4.05 \\
\hline & $S D$ & 6 & 0.67 & 53 & 0.57 & 0.65 & 0.54 \\
\hline \multirow{2}{*}{ pthers } & $\mathrm{Mea}$ & 4.42 & 3.75 & 3.63 & 3.85 & 4.21 & 3.97 \\
\hline & $S D$ & p.59 & 1.06 & 1.59 & 21 & 90 & 07 \\
\hline \multicolumn{2}{|l|}{ Fvalue } & 0.22 & 0.23 & 4.59 & 2.75 & 1.86 & 2.13 \\
\hline \multicolumn{2}{|l|}{ Pvalue } & 0.79 & 0.80 & 0.01 & 0.07 & 0.15 & 0.11 \\
\hline \multirow{3}{*}{$\begin{array}{l}\text { Marital } \\
\text { status } \\
\text { Married }\end{array}$} & Mean & .11 & 4.00 & 4.14 & 4.09 & 4.07 & 4.08 \\
\hline & $S D$ & p.68 & 0.64 & 0.51 & 0.56 & p.62 & p.511 \\
\hline & Mean & 11 & 3.95 & 4.16 & 4.12 & 4.14 & 4.09 \\
\hline $\begin{array}{l}\text { Unmarr } \\
\text { ed }\end{array}$ & $S D$ & 0.69 & 0.69 & 0.55 & p.58 & p.63 & 0.54 \\
\hline \multirow[b]{2}{*}{ Others } & Mean & 3.77 & 3.85 & 4.30 & 3.88 & 3.54 & 3.86 \\
\hline & $S D$ & 1.27 & 1.34 & 1.08 & 1.47 & 1.64 & 1.32 \\
\hline \multicolumn{2}{|l|}{ Fvalue } & 0.28 & 0.29 & 0.91 & 0.32 & 0.47 & 0.62 \\
\hline
\end{tabular}

\begin{tabular}{|c|c|c|c|c|c|c|c|}
\hline \multicolumn{2}{|l|}{ Pvalue } & 0.74 & 0.75 & 0.40 & 0.72 & 0.62 & 0.53 \\
\hline \multirow{2}{*}{ Experie } & Mean & 4.03 & 3.89 & 4.12 & 4.04 & 4.06 & 4.02 \\
\hline & $S D$ & 0.65 & p.70 & 0.52 & 0.57 & 0.65 & 0.52 \\
\hline \multirow[b]{2}{*}{$2-5$} & Mean & 4.19 & 4.01 & 4.16 & 4.14 & 4.14 & 4.13 \\
\hline & $S D$ & 0.65 & p.68 & 0.55 & p.59 & p.64 & 0.53 \\
\hline \multirow[b]{2}{*}{$5-10$} & Mean & 4.07 & 4.00 & 4.18 & 4.12 & 4.13 & 4.10 \\
\hline & $S D$ & 0.69 & 0.57 & p.46 & 0.5 & p.49 & p.44 \\
\hline \multirow[b]{2}{*}{$11-15$} & Mean & 3.45 & 3.79 & 4.11 & 3.83 & 3.63 & 3.76 \\
\hline & $S D$ & 0.79 & 0.66 & 0.55 & 0.5 & 0.74 & 0.55 \\
\hline \multirow{2}{*}{$\begin{array}{l}16 \text { and } \\
\text { above }\end{array}$} & Mean & 3.61 & 3.63 & 3.88 & 3.64 & 3.47 & 3.64 \\
\hline & $S D$ & 0.99 & 1.10 & 0.77 & 1.1 & 1.11 & 1.00 \\
\hline \multicolumn{2}{|l|}{ F Value } & 5.68 & 5.69 & p.68 & 0.56 & 2.64 & 3.25 \\
\hline \multicolumn{2}{|l|}{ Pvalue } & p.00 & p.00 & p.61 & p.69 & p.03 & p.01 \\
\hline \multicolumn{2}{|c|}{ Working Mean } & 4.47 & 4.03 & 4.19 & 4.12 & 4.08 & 4.17 \\
\hline \multirow[t]{2}{*}{$\begin{array}{l}\text { pours } \\
\text { p-6 }\end{array}$} & $S D$ & 0.25 & p.48 & p.19 & 0.22 & 0.382 & 0.15 \\
\hline & Mean & 4.28 & 4.11 & 4.24 & 4.15 & 4.13 & 4.18 \\
\hline \multirow[t]{2}{*}{$7-8$} & $S D$ & 0.53 & 0.44 & 0.33 & p.44 & 0.317 & 0.27 \\
\hline & Mean & 4.07 & 3.96 & 4.14 & 4.1 & 4.08 & 4.07 \\
\hline $9-10$ & $S D$ & 0.70 & p.68 & 0.55 & 0.59 & 0.66 & 0.54 \\
\hline \multirow{2}{*}{$\begin{array}{l}11 \text { and } \\
\text { above }\end{array}$} & Mean & 4.35 & 4.13 & 4.21 & 4.09 & 4.25 & 4.21 \\
\hline & $S D$ & 0.62 & 0.73 & 0.53 & p.63 & p.68 & 0.58 \\
\hline \multicolumn{2}{|l|}{ Fvalue } & 2.34 & 2.34 & 1.07 & p.31 & 0.05 & 0.66 \\
\hline \multicolumn{2}{|l|}{ Pvalue } & 0.07 & p.07 & 0.36 & 0.82 & 0.98 & 0.57 \\
\hline \multirow{2}{*}{$\begin{array}{l}\text { Shift } \\
\text { system } \\
\text { pay }\end{array}$} & Mean & 4.06 & 3.97 & 4.14 & 4.08 & 4.08 & 4.07 \\
\hline & $S D$ & 0.71 & p.69 & 0.54 & 0.59 & 0.65 & 0.54 \\
\hline \multirow{3}{*}{ Night } & Mean & 4.48 & 4.20 & 4.30 & 4.3 & 4.28 & 4.31 \\
\hline & $S D$ & 0.35 & p.50 & p.36 & p.44 & p.388 & 0.32 \\
\hline & Mean & 4.06 & 3.82 & 4.05 & 4.03 & 4.02 & 3.99 \\
\hline Pthers & $S D$ & 0.69 & p.65 & p.62 & p.65 & p.82 & p.60 \\
\hline \multicolumn{2}{|l|}{ Fvalue } & 5.91 & 5.91 & 2.28 & 2.55 & 3.23 & 4.27 \\
\hline \multicolumn{2}{|l|}{ Palue } & 0.00 & p.00 & p.10 & p.08 & 0.04 & p.01 \\
\hline
\end{tabular}

ANOVA and $t$ test are used for scrutiny of mean differences of the demographic variables with the dimensions of Organizational performance. Age of the employees was found to be significantly different with all the dimensions of organizational performance. Gender wise there was no noteworthy mean variation with dimensions of organizational performance except case of organization commitment. Education, marital status and working hours of the employees' were not significantly different with the dimensions of organizational performance. Experience and shift system of the employees' was significantly different with the organizational performance.

Published By

Blue Eyes Intelligence Engineering \& Sciences Publication 
Table III. Analysis of Demographic variables with the dimensions of Emotional intelligence

\begin{tabular}{|c|c|c|c|c|c|c|}
\hline \multicolumn{2}{|c|}{$\begin{array}{l}\text { Demographi } \\
\text { c variable } \\
\end{array}$} & SA & SM & SoA & $\mathbf{R M}$ & EI \\
\hline \multicolumn{7}{|l|}{ Age } \\
\hline \multirow{2}{*}{$21-30$} & Mean & 4.17 & 4.29 & 4.07 & 4.17 & 4.18 \\
\hline & $S D$ & 0.58 & 0.56 & 0.59 & 0.60 & 0.50 \\
\hline \multirow[b]{2}{*}{$31-40$} & Mean & 4.22 & 4.33 & 4.09 & 4.23 & 4.22 \\
\hline & $S D$ & 0.53 & 0.45 & 0.45 & 0.47 & 0.39 \\
\hline \multirow[b]{2}{*}{$41-50$} & Mean & 4.08 & 3.71 & 3.60 & 3.64 & 3.76 \\
\hline & $S D$ & 0.59 & 1.01 & 0.57 & 0.67 & 0.71 \\
\hline \multirow{2}{*}{$\begin{array}{l}50 \text { and } \\
\text { above }\end{array}$} & Mean & 3.25 & 3.29 & 3.30 & 2.92 & 3.19 \\
\hline & $S D$ & 1.30 & 1.41 & 1.56 & 1.53 & 1.45 \\
\hline \multicolumn{2}{|l|}{ F value } & 1.80 & 1.80 & 2.53 & 3.51 & 3.99 \\
\hline \multicolumn{2}{|l|}{ Pvalue } & 0.14 & 0.15 & 0.06 & 0.02 & 0.01 \\
\hline \multicolumn{7}{|l|}{ Gender } \\
\hline \multirow{2}{*}{ Male } & Mean & 4.25 & 4.32 & 4.10 & 4.22 & 4.22 \\
\hline & $S D$ & 0.54 & 0.49 & 0.57 & 0.55 & 0.46 \\
\hline \multirow{2}{*}{ Female } & Mean & 4.09 & 4.24 & 4.03 & 4.12 & 4.12 \\
\hline & $S D$ & 0.60 & 0.61 & 0.57 & 0.63 & 0.53 \\
\hline \multicolumn{2}{|l|}{ t-value } & 0.63 & 0.63 & 2.15 & 0.12 & 1.55 \\
\hline \multicolumn{2}{|l|}{ Pvalue } & 0.42 & 0.43 & 0.14 & 0.73 & 0.21 \\
\hline \multicolumn{7}{|c|}{ Education } \\
\hline \multirow{2}{*}{$U G$} & Mean & 4.20 & 4.30 & 4.03 & 4.18 & 4.18 \\
\hline & $S D$ & 0.58 & 0.58 & 0.61 & 0.65 & 0.53 \\
\hline \multirow{2}{*}{$P G$} & Mean & 4.16 & 4.28 & 4.11 & 4.18 & 4.18 \\
\hline & $S D$ & 0.56 & 0.52 & 0.53 & 0.52 & 0.45 \\
\hline \multirow{2}{*}{ Others } & Mean & 4.00 & 4.64 & 4.10 & 4.00 & 4.19 \\
\hline & $S D$ & 1.18 & 0.51 & 0.99 & 1.18 & 0.96 \\
\hline \multicolumn{2}{|l|}{ Fvalue } & 0.22 & 0.23 & 0.88 & 0.24 & 0.88 \\
\hline \multicolumn{2}{|l|}{ P value } & 0.79 & 0.80 & 0.42 & 0.79 & 0.42 \\
\hline \multicolumn{7}{|c|}{ Marital status } \\
\hline \multirow{2}{*}{ Married } & Mean & 4.20 & 4.31 & 4.04 & 4.19 & 4.19 \\
\hline & $S D$ & 0.53 & 0.50 & 0.55 & 0.56 & 0.45 \\
\hline \multirow{2}{*}{\begin{tabular}{|l|} 
Unma \\
rried
\end{tabular}} & Mean & 4.15 & 4.26 & 4.10 & 4.16 & 4.17 \\
\hline & $S D$ & 0.61 & 0.59 & 0.58 & 0.59 & 0.52 \\
\hline \multirow[b]{2}{*}{ Others } & Mean & 4.20 & 4.29 & 4.20 & 4.10 & 4.20 \\
\hline & $S D$ & 1.05 & 1.12 & 1.14 & 1.29 & 1.15 \\
\hline \multicolumn{2}{|l|}{ F value } & 0.11 & 0.12 & 0.20 & 0.09 & 0.08 \\
\hline \multicolumn{2}{|l|}{ P value } & 0.88 & 0.89 & 0.82 & 0.91 & 0.92 \\
\hline \multicolumn{2}{|c|}{ Experience } & & & & & \\
\hline
\end{tabular}

\begin{tabular}{|c|c|c|c|c|c|c|}
\hline \multirow{2}{*}{$0-1$} & Mean & 3.98 & 4.22 & 4.09 & 4.06 & 4.09 \\
\hline & $S D$ & 0.60 & 0.66 & 0.58 & 0.55 & 0.52 \\
\hline \multirow[b]{2}{*}{$2-5$} & Mean & 4.21 & 4.31 & 4.07 & 4.21 & 4.20 \\
\hline & $S D$ & 0.57 & 0.55 & 0.59 & 0.61 & 0.50 \\
\hline \multirow[b]{2}{*}{$6-10$} & Mean & 4.24 & 4.32 & 4.09 & 4.19 & 4.21 \\
\hline & $S D$ & 0.53 & 0.45 & 0.52 & 0.52 & 0.41 \\
\hline \multirow[b]{2}{*}{$11-15$} & Mean & 4.10 & 4.19 & 4.10 & 4.14 & 4.13 \\
\hline & $S D$ & 0.45 & 0.39 & 0.38 & 0.34 & 0.32 \\
\hline \multicolumn{2}{|c|}{16 andMean } & 3.89 & 4.00 & 3.73 & 3.69 & 3.83 \\
\hline \multicolumn{2}{|c|}{ above $S D$} & 0.84 & 0.87 & 0.82 & 0.92 & 0.85 \\
\hline \multicolumn{2}{|c|}{ Fvalue } & 1.64 & 1.65 & 2.06 & 0.88 & 1.15 \\
\hline \multicolumn{2}{|c|}{ P value } & 0.16 & 0.16 & 0.09 & 0.48 & 0.33 \\
\hline
\end{tabular}

The above table III depicts the analysis of mean differences of demographic variables with that of elements of Emotional intelligence levels of the employees'. The age of the employees' was found to be significantly different with the dimensions of emotional intelligence levels of employees'. Gender, Education, Marital status and work experience of the employees' was not significantly different with their emotional intelligence levels.

B. $\mathrm{H}_{1 \mathrm{a}}$ : There is significant association between the Ability to predict stress and Emotional Intelligence levels of the employees'.

Regression is being used for the analysis of the above hypothesis. Before testing the association between ability to predict stress and Emotional intelligence, correlation is applied in order to test the interrelatedness of the two variables. The table IV shows that the Pearson correlation coefficient is 0.668 , which means that $66.8 \%$ of positive correlation exists in between ability to predict stress and emotional intelligence levels of employees'.

\section{Table IV. Correlations}

\begin{tabular}{|l|l|l|}
\hline Variables & $\begin{array}{l}\text { Emotional } \\
\text { intelligence }\end{array}$ & $\begin{array}{l}\text { Prediction of } \\
\text { stress }\end{array}$ \\
\hline Emotional intelligence & 1 & $0.668^{* *}$ \\
\hline Prediction of stress & & 1 \\
\hline **. Correlation is significant at the 0.01 level (2-tailed). \\
\hline
\end{tabular}

Table V. Regression for testing the association of Prediction of stress and Emotional intelligence

\begin{tabular}{|c|c|c|c|c|c|c|c|c|c|}
\hline \multirow{2}{*}{ Variable } & \multicolumn{2}{|c|}{ Unstandardized Coefficients } & \multirow{2}{*}{$\begin{array}{l}\text { Standardized Coefficients } \\
\text { Beta }\end{array}$} & & \multirow{2}{*}{$\mathrm{P}$} & \multicolumn{2}{|l|}{ ANOVA } & \multirow[b]{2}{*}{$\mathrm{R}$} & \multirow{2}{*}{$\mathrm{R}^{2}$} \\
\hline & B & Std. Error & & & & $\mathrm{F}$ & $\mathrm{P}$ & & \\
\hline$($ Constant $)$ & 0.63 & 0.79 & \multirow[b]{2}{*}{0.66} & 0.793 & 0.42 & \multirow{2}{*}{371.64} & \multirow{2}{*}{$0.00 \mathrm{~b}$} & \multirow{2}{*}{0.66} & \multirow{2}{*}{0.446} \\
\hline$E I$ & 3.65 & 0.19 & & 19.27 & 0.00 & & & & \\
\hline
\end{tabular}

From table $\mathrm{V}$ is result of regression analysis is clear. In this dependent variable is prediction of stress and self-governing variable is emotional intelligence. $\mathrm{R}$ square value is 0.446 , which means that $44.6 \%$ of prediction of stress is being defined as a result of emotional intelligence levels of employees'. The coefficient of emotional intelligence is 3.657 which indicate that for every one unit of increase in emotional intelligence leads to 3.657 increases in the ability to predict stress. The $\mathrm{p}$ value is less than

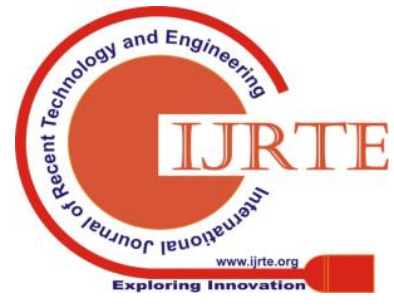


0.01 at $1 \%$ of significance level. Hence, it can be fulfilled that there is significant positive association between the prediction

\begin{tabular}{|l|l|l|}
\hline Variables & EI & JS \\
\hline$E I$ & 1 & $0.618^{* *}$ \\
\hline$J S$ & \multicolumn{2}{|l|}{1} \\
\hline$* *$. Correlation is significant at the 0.01 level (2-tailed). \\
\hline
\end{tabular}

stress

and emotion intellig

ence levels of employees'.

C. H1b: There is significant association between the Emotional intelligence levels of the employees and their job satisfaction levels.

Regression is used for the analysis of above hypothesis. Interrelatedness between the variables is tested by using correlation. The results are interpreted in the table VI. Pearson correlation coefficient is 0.618 , which indicates $61.8 \%$ of constructive association among two variables.

TABLE VI. CORRELATIONS

TABLE VII. REGRESSION FOR TESTING THE ASSOCIATION OF JOB SATISFACTION AND EMOTIONAL INTELLIGENCE

\begin{tabular}{|c|c|c|c|c|c|c|c|c|c|}
\hline \multirow{2}{*}{ Variable } & \multicolumn{2}{|c|}{ Unstandardized Coefficients } & \multirow{2}{*}{\begin{tabular}{|l|} 
Standardized Coefficients \\
Beta
\end{tabular}} & \multirow[b]{2}{*}{$\tau$} & \multirow{2}{*}{$\mathrm{P}$} & \multicolumn{2}{|l|}{ ANOVA } & \multirow[b]{2}{*}{$\mathrm{R}$} & \multirow{2}{*}{$\mathrm{R}^{2}$} \\
\hline & B & Std. Error & & & & $\mathrm{F}$ & $\mathrm{P}$ & & \\
\hline (Constant) & 4.71 & 1.43 & \multirow{2}{*}{0.61} & 3.29 & 0.001 & \multirow{2}{*}{284.914} & \multirow{2}{*}{$0.000^{\mathrm{b}}$} & \multirow{2}{*}{0.618} & \multirow{2}{*}{0.382} \\
\hline$E I$ & 5.73 & 0.34 & & 16.87 & .000 & & & & \\
\hline \multicolumn{10}{|c|}{ a. Dependent Variable: Job satisfaction } \\
\hline \multicolumn{10}{|c|}{ ant, emotional intelligence } \\
\hline
\end{tabular}

Those over table VII interprets those relapse aftereffect. That subordinate variable will be employment fulfillment and autonomous variable will be Enthusiastic brainpower. That $r$ square worth may be 0.382 , which specify that $38.2 \%$ job fulfillment is defined by the emotional intelligence levels of the employees'. It is a very moderate impact of emotional intelligence on job fulfillment levels of the employees'. The coefficient of Emotional intelligence is 5.739, means that every one unit of increase in emotional intelligence levels of the employees' leads to increase of 5.739 in their job fulfillment levels. The $\mathrm{p}$ value indicates positive noteworthy association of emotional intelligence levels of employees with job satisfaction levels.

\section{D. $\mathrm{H}_{1 \mathrm{c}}$ : There is significant association between the \\ Emotional intelligence levels of the employees and their Organizational commitment levels.}

Regression and correlation are used for the analyzing the above hypothesis. Correlation is used for finding the interrelatedness of the variables. The correlation result is given in the following table VIII. Pearson correlation coefficient is 0.604 , which means $60.4 \%$ of constructive association exists amid of two variables emotional intelligence and organization commitment.

Table VIII. Correlations

\begin{tabular}{|l|l|l|}
\hline Variables & EI & OC \\
\hline$E I$ & 1 & $0.604^{* *}$ \\
\hline$O C$ & 1 \\
\hline **. Correlation is significant at the 0.01 level (2-tailed). \\
\hline
\end{tabular}

Table IX. Regression test for analyzing the association of Emotional intelligence and organization commitment

\begin{tabular}{|l|l|l|l|l|l|l|l|l|l|}
\hline \multirow{2}{*}{ Variable } & Unstandardized Coefficients & Standardized Coefficients & $\mathrm{t}$ & $\mathrm{P}$ & \multicolumn{2}{|l|}{ ANOVA } & \multirow{2}{*}{$\mathrm{R}^{2}$} \\
\cline { 2 - 6 } & $\mathrm{B}$ & Std. Error & Beta & & & $\mathrm{F}$ & $\mathrm{P}$ & $\mathrm{R}$ & \\
\hline (Constant) & 0.53 & 0.221 & 0.604 & 2.428 & 0.016 & 265.203 & $0.00 \mathrm{~b}$ & 0.604 & 0.365 \\
\hline EI & 0.85 & 0.052 & 16.28 & 0.000 & & & & \\
\hline $\begin{array}{l}\text { a. Dependent Variable: Job satisfaction } \\
\text { b. Predictors : constant, emotional intelligence }\end{array}$
\end{tabular}

In the above table IX the dependent variable is organization commitment and independent variable is emotional intelligence. The $\mathrm{R}$ square value is 0.365 , which indicates that $36.5 \%$ of organization commitment is being defined by emotional intelligence. The coefficient of emotional intelligence is 0.854 which means for every 1 unit raise in emotional intelligence leads to 0.854 raise in organization commitment. The $\mathrm{p}$ value is significant and concludes significant positive relationship among organization obligation and emotional intelligence. 


\section{Emotional Intelligence and Its Impact on the Organizational Performance-using SEM}

E. $H_{1 \mathrm{~d}}$ : There is significant association between the Emotional intelligence levels of the employees and employee engagement

The above hypothesis is analyzed by regression. In order to find the interrelatedness of the two variables, correlation is used. The results of correlation are being interpreted in the following table $\mathrm{X}$.

\section{Table X. Correlation}

\begin{tabular}{|l|l|l|}
\hline Variables & EI & EE \\
\hline $\boldsymbol{E I}$ & 1 & $.734^{* *}$ \\
\hline $\boldsymbol{E E}$ & & 1 \\
\hline$* *$. Correlation is significant at the 0.01 level (2-tailed). \\
\hline
\end{tabular}

The above table $\mathrm{X}$ shows Pearson correlation coefficient as 0.734 . This means that there is $73.4 \%$ of correlation among Emotional intelligence and employee engagement.

The table XI shows the result of regression analysis. The dependent variable is employee engagement and independent variable is emotional intelligence. The $\mathrm{R}$ square value is 0.539 , which means that $53.9 \%$ of employee engagement is being explained by emotional intelligence. The coefficient of emotional intelligence is 0.803 . The $\mathrm{p}$ value is significant concluding that there is noteworthy constructive relationship among employee engagement and emotional intelligence.

Table XI. Regression test for assessing the association between emotional intelligence and employee engagement.

\begin{tabular}{|c|c|c|c|c|c|c|c|c|c|}
\hline \multirow{2}{*}{ Variable } & \multicolumn{2}{|c|}{ Unstandardized Coefficients } & \multirow{2}{*}{\begin{tabular}{|l} 
Standardized Coefficients \\
Beta
\end{tabular}} & & \multirow{2}{*}{$\mathrm{P}$} & \multicolumn{2}{|l|}{ ANOVA } & \multirow[b]{2}{*}{$\mathrm{R}$} & \multirow{2}{*}{$\mathrm{R}^{2}$} \\
\hline & B & Std. Error & & & & $\mathrm{F}$ & $\mathrm{P}$ & & \\
\hline$($ Constant $)$ & 0.793 & 0.146 & \multirow{2}{*}{0.734} & 5.444 & 0.000 & \multirow{2}{*}{538.348} & \multirow{2}{*}{$0.00^{\mathrm{b}}$} & \multirow{2}{*}{0.734} & \multirow{2}{*}{0.539} \\
\hline$E I$ & 0.803 & 0.035 & & 23.202 & 0.000 & & & & \\
\hline
\end{tabular}

$\mathrm{H}_{1 \mathrm{e}}$ : There is significant association between the Emotional intelligence levels of the employees and Quality of work life.

Table XII. Correlation

\begin{tabular}{|c|c|c|}
\hline Variables & EI & QWL \\
\hline $\boldsymbol{E I}$ & 1 & $.709^{* *}$ \\
\hline $\boldsymbol{Q W} \boldsymbol{L}$ & & 1 \\
\hline **. Correlation is significant at the 0.01 level (2-tailed). \\
\hline
\end{tabular}

Correlation is applied for analyzing interrelatedness between emotional intelligence and quality of work life. The Pearson correlation coefficient is 0.709 which indicates that $70.9 \%$ of correlation exists among the two variables.

Table XIII. Regression test of testing the association of emotional intelligence and quality of work life.

\begin{tabular}{|c|c|c|c|c|c|c|c|c|c|}
\hline \multirow{2}{*}{ Variable } & \multicolumn{2}{|c|}{ Unstandardized Coefficients } & \multirow{2}{*}{$\begin{array}{l}\text { Standardized Coefficients } \\
\text { Beta }\end{array}$} & \multirow{2}{*}{$\mathrm{t}$} & \multirow{2}{*}{$\mathrm{P}$} & \multicolumn{2}{|l|}{ ANOVA } & \multirow[b]{2}{*}{$\mathrm{R}$} & \multirow{2}{*}{$\mathrm{R}^{2}$} \\
\hline & B & Std. Error & & & & $\mathrm{F}$ & $\mathrm{P}$ & & \\
\hline (Constant) & 0.542 & 0.166 & \multirow{2}{*}{0.709} & 3.254 & 0.001 & \multirow{2}{*}{464.704} & \multirow{2}{*}{$0.00^{\mathrm{b}}$} & \multirow{2}{*}{0.709} & \multirow{2}{*}{0.502} \\
\hline$E I$ & 0.853 & 0.040 & & 21.557 & 0.000 & & & & \\
\hline
\end{tabular}

The table XIII shows the regression result. The R square value is 0.502 . This means $50.2 \%$ of quality of work life is being explained through emotional intelligence. The coefficient of emotional intelligence is 0.853 which indicates for every one unit raise in the emotional intelligence there will be 0.853 raise in quality of work life. The p value is less than 0.01 at $1 \%$ significance level. Hence it can be said that there is significant optimistic association among emotional intelligence and quality of work life.
F. $\mathrm{H}_{2}$ : There is significant association between the Emotional intelligence levels of employees' and their organizational performance levels.

In the above table XIV, the dependent variable is organizational performance and independent variable is emotional intelligence. The $\mathrm{R}$ square value is 0.597 , which indicates $59.7 \%$ of organizational performance is explained through emotional intelligence. The coefficient of emotional intelligence is 0.849 ,

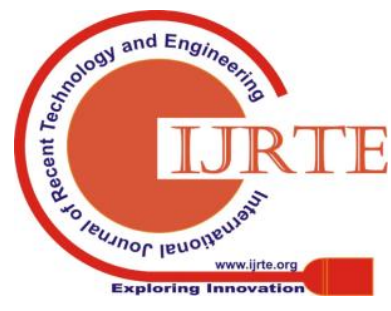


which means that organizational performance increases by 0.849 with the increase of one unit in emotional intelligence. The $\mathrm{p}$ value is less than 0.01 at $1 \%$ of significance level. Hence, it can be confirmed noteworthy positive relationship among emotional intelligence and organizational performance.

Table XIV. Regression for assessing the association between emotional intelligence and organizational performance.

\begin{tabular}{|c|c|c|c|c|c|c|c|c|c|}
\hline \multirow{2}{*}{ Variable } & \multicolumn{2}{|c|}{ Unstandardized Coefficients } & \multirow{2}{*}{\begin{tabular}{|l} 
Standardized Coefficients \\
Beta
\end{tabular}} & \multirow{2}{*}{$\mathrm{t}$} & \multirow{2}{*}{$\mathrm{P}$} & \multicolumn{2}{|c|}{ ANOVA } & \multirow[b]{2}{*}{$\mathrm{R}$} & \multirow{2}{*}{$\mathrm{R}^{2}$} \\
\hline & B & Std. Error & & & & $\mathrm{F}$ & $\mathrm{P}$ & & \\
\hline (Constant) & 0.541 & 0.137 & \multirow{2}{*}{0.773} & 3.956 & 0.000 & \multirow{2}{*}{683.491} & \multirow{2}{*}{$0.00^{\mathrm{b}}$} & \multirow{2}{*}{0.773} & \multirow{2}{*}{0.597} \\
\hline$E I$ & 0.849 & 0.032 & & 26.144 & 0.000 & & & & \\
\hline
\end{tabular}

\section{G. Structural Equation Model:}

Structural equation model is used for assessing the hypothesis of the study. This is being done in two stages. Initial stage is the measurement model which helps in evaluating the causal relationship and the second stage is the structural model.

Relationship between emotional intelligence and organizational performance:

The relationship between the dependent variable organizational performance and independent variable emotional intelligence is being analyzed and the results are tabulated in the table XV.

The table XV shows the goodness of fit indices. It is observed that all the values are within the prescribed goodness of fit values. Hence, we can say that the data fits into structural model.

\section{Fig 2 Causal Relationship}

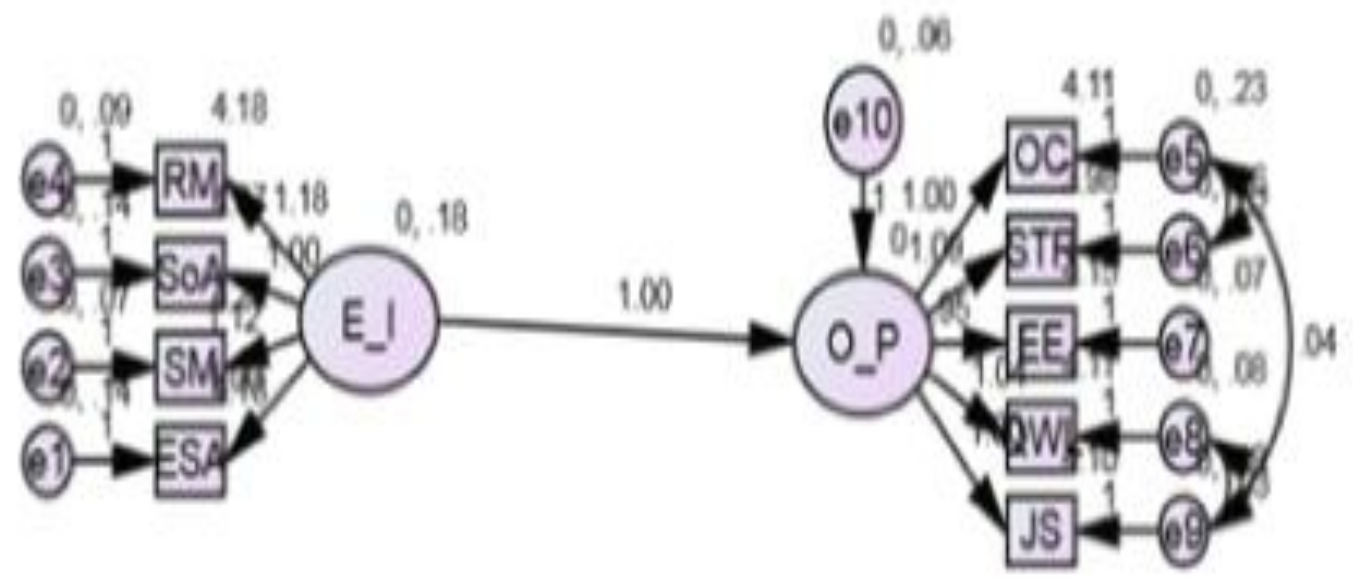

Table XV. summary of the model

The above figure 1 shows the causal association among Emotional intelligence and organizational performance.

\begin{tabular}{|c|c|c|c|c|c|c|c|c|}
\hline Hypothesis & Variables & & & $\begin{array}{l}\text { Unstandardized } \\
\text { coefficients }\end{array}$ & $\begin{array}{l}\text { Standardized } \\
\text { coefficients }\end{array}$ & $\begin{array}{l}\text { Standard } \\
\text { error }\end{array}$ & $t$ value & $\mathbf{P}$ \\
\hline$H_{03}$ & ORG_PER & <-- & EMO_INT & 1.002 & 0.873 & 0.072 & 13.99 & $* * *$ \\
\hline
\end{tabular}

$* * *$ significant at $1 \%$ level 
The above table XVI depicts the beta value, $\mathrm{t}$ value and $\mathrm{p}$ value. The $\mathrm{p}$ value is said to significant at $1 \%$ level of significance. Hence, we can conclude that the result shows the casual bond among emotional intelligence and organizational performance.

\section{DISCUSSION:}

The findings in the study show that the age, work experiences and shift system of the employees' was found to be significantly different with the means of organizational performance. Age of the employees' was significantly different with the means of emotional intelligence levels. Job fulfillment levels and organization obligation levels of employees' were having low association with their emotional intelligence levels. The result regarding job satisfaction is just opposite to the result obtained in an investagation conducted by Samaneh et al (2011). The study done by Hassan (2015) has a similar result that Emotional intelligence is having moderate control on organization commitment levels of employees'. Ability to predict stress, employee engagement, quality of work life was having moderate association with emotional intelligence levels of employees'. Overall emotional intelligence levels of employees' was having moderate association with organizational performance. This result match with result of The organization hence should include emotional intelligence as a part of its recruitment and selection process. The retained employees' should be provided with training to develop their emotional intelligence levels. The leaders and supervisory level staff should be provided training to develop their emotional intelligence levels. This helps them to support and guide their employees'.

The organizations should conduct stress audit and should be able to identify levels of stress that the employees' are facing. Along with the identification of stress levels the employees' should also be counseled in applying the strategies for overcoming the stress. The organization should have an open door policy system and the employees' are to be given an opportunity to have voice in the planning and decision making process.

The organization should assess the dissatisfied factors of employees' and should plan accordingly to satisfy the employees'. The organizational culture should be made more comfortable for the employees' to make them to give their best for attainment of goals.

\section{CONCLUSION:}

The examination uncovers that there is a vital impact of the passionate insight on hierarchical execution. The organizations' should concentrate on developing emotional intelligence levels of employees'. Emotional intelligence is playing a very crucial role in most of the aspects of organizational performance. Hence, the IT companies have to center on development of emotional brains levels of employees'.

\section{REFERENCES}

[1]. Aghdasi, S., Kiamanesh, A. R., \& Ebrahim, A. N. (2011). Emotional intelligence and organizational commitment: Testing the mediatory role of occupational stress and job satisfaction. Procedia - Social and Behavioral Sciences, 29(October 2016), 1965-1976. https://doi.org/10.1016/j.sbspro.2011.11. 447

[2]. Lahore, D., Report, S., Intelligence, E., Scale, J. S., Intentions, T., \& Scale, P. (2016). European Journal of Social Sciences Studies Emotional Intelligence As A Predictor Of, (716).

[3]. Ntwari, A., \& Kule, W. J. (2016). The International Journal of Business \& Management Role of Strategic Human Resource Management Practices on the Performance of Financial Institutions in Rwanda : Case Study of Bank of Kigali, 4(4), 511-520.

[4]. International, T., \& Of, J. (2015). The International Journal of Business \& Management The Impact of Employee Engagement in Improving Organizational Performance Abstract: The International Journal of Business \& Management, 3(2), 111-114.

[5]. Sarangi, S., \& Vats, A. (2015). Role of Emotional Intelligence on Employee Engagement: A Study among Indian Professionals. International Journal of Business and Management, $\quad$ 10(6), 224-234 https://doi.org/10.5539/ijbm.v10n6p224

[6]. Mwangi, D. C. I. (2014). Emotional Intelligence Influence on Employee Engagement Sustainability in Kenyan Public Universities. International Journal of Academic Research in Public Policy and Governance, 1(1), 75-92. https://doi.org/10.6007/ijarppg/v1-i1/920

[7]. Gul, Z. (2015). Impact of Employee Commitment on Organizational Performance. FWU Journal of Social Sciences, Winter 2015, 9(2), 117-124.

[8]. Berberoglu, A., \& Secim, H. (2015). Organizational Commitment and Perceived Organizational Performance Among Health Care Professionals : Empirical Evidence From A Private Hospital in Northern Cyprus. Journal of Economics and Behavioral Studies, 7(1), 64-71.

[9]. Shafiq, M., \& Rana, R. A. (2016). Relationship of Emotional Intelligence to Organizational Commitment of College Teachers in Pakistan. Eurasian Journal of Educational Research, 16(62), 1-14 https://doi.org/10.14689/ejer.2016.62.1

[10].Patiraj and Bhanu (2015). Commerce Management The Role of Emotional Intelligence in Organizational Commitment : a Study of Banking Sector Prof . Patiraj Kumari Bhanu Priya Professor , Department of Management Studies ) Kanya Gurukul Campus ,

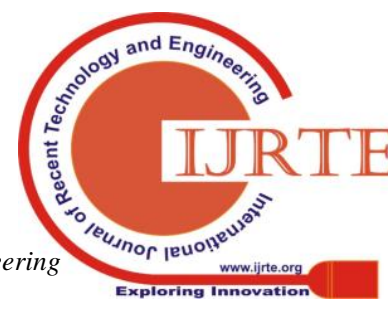


Dehradun Research Scholar, Department , (11), 59-62.

[11].Bakotić, D. (2016). Relationship between job satisfaction and organisational performance. Economic Research-Ekonomska Istraživanja, 29(1), 118-130. https://doi.org/10.1080/1331677X.2016.1163946

[12].Shmailan, A. (2016). The Relationship between Job Satisfaction, Job Performance and Employee Engagement: An Explorative Study. Issues in Business Management and Economics, 4 (1)(January), $1-8$. https://doi.org/10.15739/IBME.16. 001

[13].Prasad, K., Vaidya, R., \& Kumar, V. A. (2016). An empirical study on the causes of occupational stress and its effect on performance at the workplace of supermarkets in hyderabad. Innovative Journal of Business and Management, (July), 89-93. https://doi.org/10.15520/ijbm.vol5.iss5.55.pp94-101

[14]. Sathya Priya, V. B. (2016). A Study on Job Stress and its Impact on Employees. International Journal of Management, $7(2), 247-254$.

[15].Sharma, R., \& Kumar, P. (2016). Emotional Intelligence and Stress Coping Styles: A Study of Doctors of Private Hospitals in and Around Chandigarh. IRA-International Journal of Management \& Social Sciences (ISSN 2455-2267), 3(3). doi:http://dx.doi.org/10.21013/jmss.v3.n3.p24

[16]. Sharma, R., \& Sharma, K. (2014). The Relationship Between Emotional Intelligence and Occupational Stress : A Study on BPO SEGMENT IN INDIA. Journal of Strategic Human Resource Management, 3(3), 19-25.

[17].Quadros, A. R. A. (2015). Employee Perception on Organizational Performance : A Structural Equation Modeling Approach. The International Journal of Business \& Management, 3(5), 252-257. Retrieved from www.theijbm.com

[18].Jaiswal, A. (2014). Quality Of Work Life. Journal of Business Management \& Social Sciences Research, 3(2), 83-87.

[19]. Manhas, C. (2013). Relating Emotional Intelligence, Quality of Work Life and Job Satisfaction : A Study among Corporate Employees, 2(April), 107-121.

[20].Farahbakhsh, S. (2012). The role of emotional intelligence in increasing quality of work life in school principals, 46, 31-35. https://doi.org/10.1016/j.sbspro.2012.05.062

[21].Karolis, K. (2016). The impact of the manager's emotional intelligence on organisational performance. Management Theory and Studies for Rural Business and Infrastructure Development, $\quad 38(1), \quad$ 58-69. https://doi.org/10.15544/mts.2016.6

[22]. Intelligence, E., Performance, O., Associate, P., \& Services, A. (2014). Emotional Intelligence Self - awareness Self management Social awareness Relationship management Employee Performance, 3(12), 1-8.

[23]. Papathanasiou, S., \& Siati, M. (2014). Emotional Intelligence and Job Satisfaction in Greek Banking Sector. Research in
Applied Economics, 6(1),

https://doi.org/10.5296/rae.v6i1.5050

[24].Masrek, M. N., Akmal, M., Osman, F., Khamis, Y., \& Paiman, M. J. (2014). The Relationship Between Emotional Intelligence and Job Satisfaction: The Case of Malaysian Information Technology Professionals. International Journal of Multidisciplinary and Current Research, 2(Nov/Dec), 1106-1111. 